\title{
Studies on the Epidemiology of Leaf Rot and Leaf Spot Diseases of Betel Vine ( Piper Betle L.)
}

\author{
M I. Huq* \\ RARS, Rahmatpur, Barisal
}

\begin{abstract}
The experiment was conducted in an established pan betel vine crop field (Pan boroj). The disease data were recorded for 12 months. The incidence of leaf rot was observed in the month of June, July and August. The peak infection was noted in the second week of August, 2002 when the average temperature, relative humidly and rainfall were $29.60^{\circ} \mathrm{C}, 94.6 \%$ and $13.4 \mathrm{~mm}$ respectively. The incidence of leaf spot was observed during months of March, April and May. But gradually infection reached maximum when average temperature, relative humidly and rainfall parameters were $26.7^{\circ} \mathrm{C}, 88.3 \%$ and $19.4 \mathrm{~mm}$ respectively. The meteorological factor which had greatly influenced initiation of leaf spot was less favourable for leaf rot disease.
\end{abstract}

Key words: Epidemiology, Betel vine, Leaf spot and Leaf rot diseases

\section{Introduction}

Betel vine (Piper betle L.) having the heart shaped deep green leaves is an important horticultural crop of aesthetic and commercial values. The perennial climber is grown throughout the country. There are about 100 varieties of betel leaf (pan) across the world of which 40 are encountered in India and 30 in west Bengal and Bangladesh (Guha 1997; Maity, 1989; Samanta, 1994). The most probable place of origin of Pan is Malayasia (Chattopadhyay and Maity, 1967). Pan contains some vitamins, enzymes, thiamine, riboflavin, tannin, iodine, iron, calcium, minerals, protein, essential oil and medicine for liver, brain and heart diseases (Chopra et al.1956; Khanra 1997). Apart from the serological aspects the leaves are generally offered to the guests as the symbol of hospitality. It is grown in the rainfall about 2250-4750 $\mathrm{mm}$, relative humidity and temperature ranging from 40$80 \%$ and $15-90^{\circ} \mathrm{C}$ respectively (Guha and Jain, 1997). This perennial crop is found to be infected by various diseases of which leaf rot and leaf spot caused by pathogens, Phytophthora parasitica and Colletotrichum capsici are the major constraints for cultivation of the crop across the country (Goswami et al. 2002). Leaf rot can damage the crop within a week when it attacks the vine (Chaurasia 1994). Leaf rot and foot rot have been reported to be caused by Phytophthpra palmivora and leaf rot may cause 30-100\% leaf yield loss (Maiti and Sen 1997). The relative humidity enhances the incidence of the leaf rot disease (Kumar and Kumar, 2004). Although some information about the control measure of the above mentioned diseases are available but influence of environmental factors on disease development are not much known and comprehensive attempts on epidemiology of the diseases have not been made so far. So, attempts have been made to study the epidemiology of leaf rot and leaf spot diseases of betel leaf of economic importance.

\section{Materials and Methods}

The experiment has been conducted at the Regional Agricultural Research Station, Rahmatpur, Barisal. Fortnightly data were recorded from an established Betel Vine Cultivation Field in Bengali called as pan boroj starting from the month of June, 2002 and continued till May, 2003. The disease severity of leaf spot was recorded using 0-5 scoring scale from 25 randomly collected leaves as described by Goswami el al. (2002),

$0=$ Healthy leaf, $1=\mathrm{Up}$ to $5 \%$ leaf area covered, $2=6-15 \%$ leaf area covered, $3=16-30 \%$ leaf area covered, $4=31-50$ $\%$ leaf area covered and $5=$ above $50 \%$ leaf area covered. The disease severity of leaf rot was recorded using 0-5 scoring scale from 25 randomly collected leaves as described by Goswami et al. (1993)

$0=$ no or a few lesion on leaf, $1=\mathrm{Up}$ to $10 \%$ leaf area affected, $2=11-25 \%$ leaf area affected, $3=26-50 \%$ leaf area

\footnotetext{
*Corresponding author. E-mail: huqrars@gmail.com
} 
affected , $4=51-75 \%$ leaf area affected and $5=$ above $75 \%$ leaf area affected. The Percent Disease Index was computed based on the formula as described below by Wheeler, (1969).

PDI $=\frac{\text { Sum of numerical values }}{\text { No. of plant parts observed }} \times \frac{100}{\text { Maximum disease rating }}$

Disease data were correlated with the meteorological data to find out the critical weather condition for the epidemiology of the disease (Srivastava and Singh, 1994). Meteorological data were collected from the nearest Meteorological Centre (BRRI, Barisal).

\section{Results and Discussion}

From Table I, it is evident that high incidence of leaf rot was detected during the months of June, July and August. It started from June and gradually increased till August of each year under observation. From the first fortnight of September, the severity of infection decreased gradually and continued till second fortnight of May, 2003. High incidence of leaf spot was observed during the months of March, April, and May. The peak infection increased gradually in the second fortnight of September, 2002 and continued until May, 2003. The disease severity of leaf rot reached maximum in the second week of August, 2003 when the average temperature, relative humidly and rainfall gradients were $29.6^{\circ} \mathrm{C}, 94.6 \%$ and $13.4 \mathrm{~mm}$ respectively. The occurrence of leaf spot the disease reached the maximum when average temperature, relative humidly and rainfall were $26.7^{\circ} \mathrm{C}, 88.3 \%$ and 19.4 $\mathrm{mm}$ respectively. Sindhan and Bose (1980) reported that atmospheric temperature and humidity are important meteorological factors for development of different diseases and increase in relative humidity due to rainfall enhances initiation of diseases.

Table I: Effect of temperature, relative humidity and rainfall on the leaf rot and leaf spot diseases of betel vine

\begin{tabular}{|c|c|c|c|c|c|}
\hline \multirow[t]{2}{*}{ Date } & \multicolumn{2}{|c|}{ PDI } & \multirow{2}{*}{$\begin{array}{c}\mathrm{RH} \% \\
\text { (Average) }\end{array}$} & \multirow{2}{*}{$\begin{array}{l}\text { Temp. }{ }^{\circ} \mathrm{C} . \\
\text { (Average) }\end{array}$} & \multirow{2}{*}{$\begin{array}{c}\text { Rain fall } \\
\text { (mm) }\end{array}$} \\
\hline & Leaf rot & Leaf spot & & & \\
\hline June (1- 15) & 66.6 & 30.4 & 93.1 & 29.7 & 22.5 \\
\hline June (16-30) & 68.9 & 34.4 & 95.3 & 29.6 & 36.5 \\
\hline July (1-15) & 69.8 & 29.6 & 93.7 & 29.8 & 21.4 \\
\hline July (16-30) & 68.4 & 32.0 & 96.9 & 31.9 & 11.5 \\
\hline Aug (1-15) & 76.8 & 34.6 & 94.6 & 29.6 & 13.4 \\
\hline Aug (16-30) & 77.9 & 32.2 & 96.1 & 31.2 & 15.6 \\
\hline Sept $(1-15)$ & 60.6 & 29.5 & 90.2 & 26.5 & 20.2 \\
\hline Sept (16-30) & 41.6 & 37.6 & 92.7 & 29.5 & 10.9 \\
\hline Oct $(1-15)$ & 38.4 & 48.6 & 87.5 & 29.8 & 9.3 \\
\hline Oct $\quad(16-30)$ & 42.5 & 52.8 & 89.5 & 29.0 & 3.8 \\
\hline Nov $(1-15)$ & 22.4 & 49.6 & 86.3 & 26.5 & 3.9 \\
\hline Nov (16-30) & 27.2 & 48.0 & 81.5 & 24.9 & - \\
\hline Dec (1-15) & 24.0 & 52.2 & 81.8 & 19.5 & - \\
\hline $\operatorname{Dec}(16-30)$ & 26.8 & 52.8 & 87.6 & 22.5 & - \\
\hline Jan $(1-15)$ & 19.8 & 54.6 & 85.5 & 17.6 & - \\
\hline Jan (16-30) & 16.5 & 54.0 & 81.4 & 19.3 & - \\
\hline Feb (1-15) & 16.6 & 54.4 & 91.0 & 22.1 & - \\
\hline Feb (16-28) & 15.8 & 58.0 & 96.1 & 24.5 & - \\
\hline Mar (1-15) & 15.6 & 58.2 & 99.1 & 24.8 & 17.2 \\
\hline Mar (16-30) & 15.6 & 62.5 & 88.2 & 26.6 & 19.4 \\
\hline Apr (1-15) & 15.5 & 62.5 & 87.5 & 27.2 & - \\
\hline Apr (16-30) & 14.8 & 62.6 & 88.0 & 27.6 & - \\
\hline May (1-15) & 12.9 & 62.6 & 88.8 & 30.1 & - \\
\hline May (16-30) & 12.2 & 63.3 & 88.95 & 30.6 & - \\
\hline
\end{tabular}


Relationships between rainfall and leaf rot, rainfall leaf and leaf spot diseases

Regression line of leaf showed linear positive correlation with mean rainfall having regression co-efficient, $\mathrm{R}_{2}=$ 0.4643 and equation $y=1.5632 x+23.721$ and linear negative correlation with leaf spot showing regression co-efficient, $\mathrm{R}_{2}=0.4627$ and equation, $\mathrm{y}=-0.8025 \mathrm{x}+54.587$ and produced the best fit (Fig,1-2).

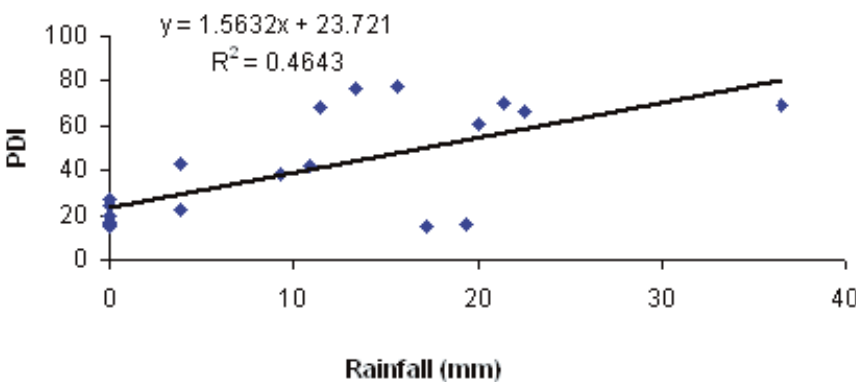

Fig. 1: Regression line showing relationship between rainfall and leaf rot

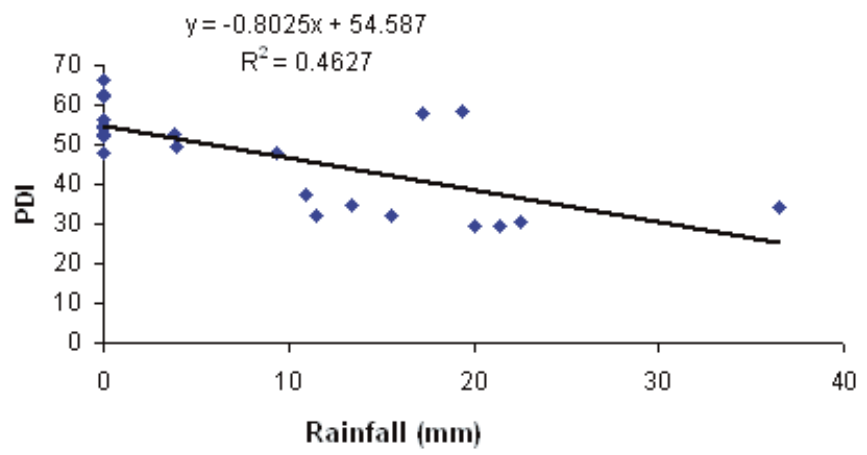

Fig. 2: Regression line showing relationship between rainfall and leaf spot

Relationships between temperature and leaf rot, temperature and leaf spot diseases

The average temperature showed linear and positive correlation with leaf rot depicting co-efficient of regression, $\mathrm{R}_{2}=$ 0.4876 and equation, $y=4.0814 x-69.36$ and negative and linear correlation with leaf spot exhibiting co-efficient of regression, $\mathrm{R}_{2}=0.3159$ and equation, $\mathrm{y}=1.6924 \mathrm{x}+91.716$ which are best fited (Fig, 3-4).

From the present study, it is apparent that leaf rot of betel vine required adequate more temperature and relative humidity for its development compared to leaf spot. It was observed that starting from second fortnight of November to

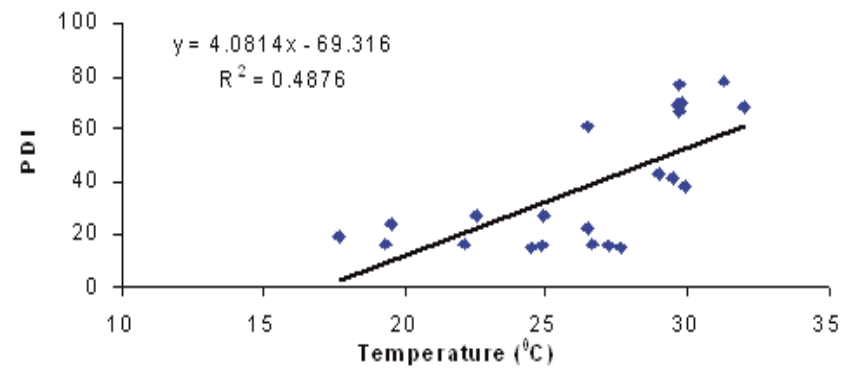

Fig. 3: Showing relationship between temperature and leaf rot disease in betel leaf

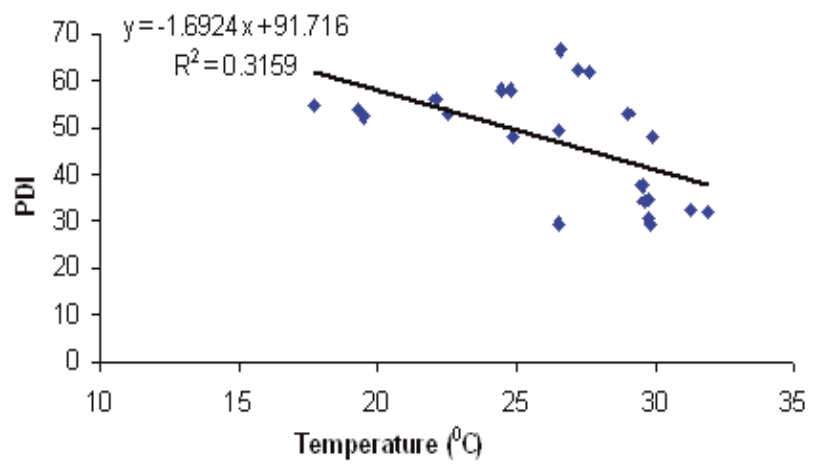

Fig. 4: Showing relationship between temperature and leaf spot disease in betel leaf

second fortnight of February there was no rainfall. Under this environmental condition, severity of leaf spot gradually increased with the decrease of leaf rot disease.

So, it may be concluded that rainfall is an important factor for spreading leaf spot but it is not essential for initiation of this disease. But for leaf rot disease, rainfall is essential during the period (second fortnight of November to second fortnight of February), in case of the severity of leaf rot having no rain, decreased gradually. Meteorological parameters like atmospheric temperature, relative humidity and rainfall are congenial for the disease (Marimathu and Rabindran, 1988). The spreading nature and development of leaf rot and leaf spot diseases are different. When incidence of leaf rot was observed higher then leaf spot was predicted lesser. The statement of Goswami et al., (1993) is in agreement with the present findings. The meteorological factors, that have been preferred for leaf spot were less favourable for leaf rot disease.

\section{Conclusion}

Leaf rot disease of betel leaf (Pan) was influenced by high atmospheric humidity and rainfall from June to August annu- 
ally. On the other hand, incidence of leaf spot increased with less humidity gradient during the months of November to March.

\section{References}

Chaurasia J. P. (1994). Studies on the management of Betelvine-Phytophthora disease in Sagar division. Ph. D. Thesis, Dr. H. S. Gour University. Sagar. 110pp

Chattapdayay S. P. and Maity S. (1967). Diseases of Betelvine and species.ICAR New Delhi

Chopra R. N., Nayar S. I. and Chopra I. C. (1965). Glossary of India Medicinal Plants, pp194. CSIR, New Delhi

Chopra, R.N., Nayar, S.L. and Chopra, I.C. (1956). Glossary of Indian Medicinal Plant. pp194. CSIR, New Delhi

Goswami B. K., Kader, K. A., Rahman M. L., Islam, M. R. and Malaker ,P. K. 2002. Development of leaf spot of betelvine caused by Colletotrichum capsici. Bangladesh J. Plant Pathol. 18(1\&2): 39-42.

Goswami B. K., Zahid M. I. and Haq, M. O. (1993). Screening of Colocasia esculenta germplasm to Phytophthora leaf blight. Bangladesh J. Plant Pathol. 9(1\&2): 21-24.

Guha, P. and Jain. (1997). Paan Theke Kutir shilpa shambhabana (In Bengali) Exploring Betel Leaves for Cottage Industriy , pp15-19

Khanra S. (1997). Paan Vittik Silpakendra (In Bangali) "Betel leaf Based Indurtry" Nabanna Bharati, 30(2): 169

Kumar C. P. C. and Kumar C. S. K. (2004). Epidemiological studies on Phytophthora foot rot disease of betel vine. Indian J. Plant Protection. 32 (2): 100-101.
Marimuthu, T. and R. Rabindran. (1988). Influence of weather factors on the incidence of foot rot and leaf rot of betelvine. Indian Phytopath. 41: 373-375.

Maiti S. and C. Sen. (1979). Leaf rot and foot rot of Piper betel caused by Phytophthora palmivora. Indian Phytopath. 30: 438-439.

Maity P. (1989). Extension Bulletin: The Betel vine. All India coordinated Researh project of betel vine. Indian Institute for Horticultural Research. Hessarghatta, Bangalore, India.

Samanta, C. (1994). Paan chasher samasyaboli -o- samadhan. India: Ekti samikkha ( In Bengali), A Report on Problem and Solutions of Betelvine Cultivation. A booklet published by Mr. H. R. Adhikarri, C-2/16 Karunamoyee, Salt Lake City, Kolkata- 64 (WB), India.

Srivastava M. and D. V. Singh. (1994). Epidemiology of leaf rot and foot rot of betel vine caused by Phytophthora parasitica at Mahoba. Indian J. Plant Pathol. 12 (1\&2): 10-12.

Sindhan, G. S. and S. K. Bose. (1980). Epidemiology of angular leaf spot of french bean caused by Phaeoisariopsis griseola. Indian Phytopath. 33 (1): 6468.

Wheeler, B. E. J. 1969. An Introduction to Plant Diseases. John Wiley and Sons. Ltd. London. pp.301.

Received: February, 12, 2009;

Accepted: March 29, 2011 